\title{
ORIGINALARTICLE
}

\section{Effect of Mediterranean saltbush (Atriplex halimus) ensilaging with two developed enzyme cocktails on feed intake, nutrient digestibility and ruminal fermentation in sheep}

\author{
Haidy ALSERSY, ${ }^{1}$ Abdelfattah Z. M. SALEM, ${ }^{1,2}$ Borhami E. BORHAMI, Jaime OLIVARES, ${ }^{3}$ Hany M. GADO, ${ }^{4}$ \\ Maria D. MARIEZCURRENA, ${ }^{5}$ Mohamed H. YACUOT, ${ }^{7}$ Ahmed E. KHOLIF, ${ }^{6}$ Mounir EL-ADAWY ${ }^{1}$ and \\ Saul R. HERNANDEZ ${ }^{3}$

\begin{abstract}
${ }^{1}$ Faculty of Agriculture, Alexandria University, Alexandria, Egypt, ${ }^{4}$ Faculty of Agriculture, Animal Production Department, Ain Shams University, ${ }^{6}$ Dairy Science Department, National Research Centre, ${ }^{7}$ Animal Production Institute, Ministry of Agriculture, Cairo, Egypt, ${ }^{2}$ Facultad de Medicina Veterinaria y Zootecnia, ${ }^{5}$ Facultad de

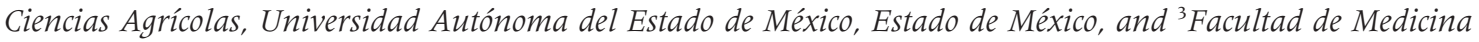
Veterinaria y Zootecnia, Carretera Altamirano - Iguala, Guerrero, México
\end{abstract}

\begin{abstract}
The aim of this study was to assess the effects of feeding Atriplex halimus (AH) silage treated with two developed enzyme cocktails to sheep on feed intake, nutrient digestibility and ruminal fermentation. The AH silage was treated without or with $2 \mathrm{~L}$ of $Z A D 1^{\oplus}$ or ZAD2 $2^{\circledast} / 1000 \mathrm{~kg}$ with $5 \%$ molasses and ensiled for 30 days. Barley grain ( $300 \mathrm{~g} / \mathrm{head} /$ day) was fed as an energy supplement once daily at 10.00 hours and AH silage with or without enzyme treatment was offered ad libitum to animals twice daily at 09.00 and 16.00 hours. Sheep were fed on four experimental forage diets comprised of AH silage and barley (D1), AH silage treated with ZAD1 ${ }^{\circledR}$ and barley (D2), AH silage treated with ZAD2 ${ }^{\circledR}$ and barley (D3) and AH silage treated with a combination of ZAD $1^{\circledR}$ and ZAD2 ${ }^{\circledR}(1: 1)$ and barley (D4). Ensiling AH with enzymes reduced its contents of neutral detergent fiber and acid detergent fiber. The dry matter intake of AH of D2, D3 and D4 decreased $(P<0.001)$ as compared to D1. However, enzyme-treated diets had greater total digestible nutrients intake $(P<0.001)$ as compared to D1. The nutrients digestibility for D2, D3 and D4 were higher than those for D1 $(P<0.001)$, and were higher for D3 as compared to both D2 and D4. Sheep fed on D3 had highest $(P<0.001)$ ruminal total volatile fatty acids concentration, ammonia nitrogen concentration and microbial protein yield. It could be concluded that AH silage treated with ZAD $1^{\oplus}$ or ZAD $2^{\circledR}$ improved digestibility and rumen fermentation in sheep.
\end{abstract}

Key words: Atriplex halimus, exogenous enzymes, feed intake, nutrient digestibility, ruminal fermentation.

\section{INTRODUCTION}

The main constraint to develop animal production in developing countries is feed shortage, both in terms of quality and quantity. Halophytic and saltbush forage shrubs are used for ruminant feed across a range of saline and arid production environments (Le Houerou 1992). Saltbushes contain high levels of crude protein (CP) (Norman et al. 2004; Al-Owaimer et al. 2011), however, much of the nitrogen $(\mathrm{N})$ is associated with non-protein compounds such as nitrates and proline. These non-protein compounds may be converted into microbial protein in the rumen or converted to ammonia depending on the availability of metabolizable energy (Pearce et al. 2010). In Egypt, tree and shrub forages play an important role in ruminant feeding in arid and semi-arid regions of the northern region of Egypt where halophyte shrubs of the genus Atriplex tend to predominate in these areas (Salem et al. 2012). However, Atriplex halimus is not highly utilized because of its deficiency of available carbohydrate and high fiber content, and therefore, barley grain as an energy source has been suggested to

Correspondence: Abdelfattah Z. M. Salem, Facultad de Medicina Veterinaria y Zootecnia, Universidad Autónoma del Estado de México, Estado de México, México. (Email: asalem70@yahoo.com) [Correction added on 9 October 2014, after first online publication: Corresponding author address has been corrected.]

Received 21 September 2013; accepted for publication 17 March 2014. 
stimulate the utilization of saltbush. Feeding a highenergy supplement such as barley grains can improve the feeding value of saltbush pastures and providing energy to ruminal microbes, stimulating carbohydrate digestion and detoxifying secondary metabolites (Mayberry et al. 2008; Norman et al. 2008). Atriplex halimus has high ash and crude fiber, and low crude fat contents. However, it contains up to $10 \%$ sodium chloride and secondary plant metabolites, including tannins, flavonoids, saponins, alkaloids and resins (Makkar 2003; Salem et al. 2006) which considerably affect its palatability and nutritive value (Abd El-Rahman et al. 2006). The processing of A. halimus by ensiling enhanced its acceptability in sheep and goats providing sufficient metabolizable energy and digestible CP to animals (Abd El-Rahman et al. 2006).

In recent years, some species of the Atriplex genus, in particular Atriplex halimus, has been cultivated as forage because of its tolerance to severe conditions of drought, and it can also grow in very alkaline and saline soils (Aharonson et al. 1969). Atriplex halimus has been studied in relation to its adaptability, productive potential, palatability and nutritive value (Norman et al. 2008; Otal et al. 2010). It is well known that addition of exogenous enzymes to animal diets can improve feeding value and animal performance by improving fiber degradation and increasing feed intake and digestion (Khattab et al. 201 1; Salem et al. 2013) as indicated by in vitro studies (Giraldo et al. 2008; Elghandour et al. 2013), in situ studies (Miller et al. 2008a; Chung et al. 2012) and in vivo studies (Gado et al. 2009; Holtshausen et al. 2011; Salem et al. 2013). Moreover, enzymes addition at forage ensiling increased both feed intake and digestion rate (Miller et al. 2008b; Salem et al. 2012). A two recently developed enzyme cocktails $\mathrm{ZADl}^{\oplus}$ and $\mathrm{ZAD}^{\circledR}$ are biotechnical products made from anaerobic bacteria from natural sources to elevate the level of cellulolytic enzymes from anaerobic bacteria, which convert polysaccharides into monosaccharide by specific enzymes (Gado et al. 2009, 2011) and their products have beneficial effects on nutritive value of poor quality roughages (Gado 1997). ZAD ${ }^{\oplus}$ differs from ZAD2 ${ }^{\circledR}$ in its different enzyme concentrations.

The objective of the present work was to evaluate the effect of treating $A$. halimus with different enzymes of $\mathrm{ZADl}^{\circledR}$ or $\mathrm{ZAD}^{\circledR}{ }^{\circledR}$ on sheep feed intake, nutrient digestibility, $\mathrm{N}$ utilization, rumen fermentation and rumen microbial protein synthesis in sheep.

\section{MATERIALS AND METHODS} A. halimus preparation

Leaves and stems of fresh Mediterranean saltbush (A. halimus) were collected from the north-western desert region in Egypt, dried and chopped to $3-5 \mathrm{~cm}$ in lengths and stored in a dry environment. The secondary metabolite concentrations of fresh $(\mathrm{g} / \mathrm{kg})$ and dried A. halimus $(\mathrm{g} / \mathrm{kg}$ dry matter $(\mathrm{DM}))$, respectively, were 13.33 and 7.21 for total phenolics, 5.45 and 2.23 for total tannin and 7.27 and 2.62 for alkaloids.

\section{Animals and treatments}

Three Barki rams $(45 \pm 3.2 \mathrm{~kg})$ were used in four consecutive trails for ad libitum feed intake and nutrients digestibility determination; and three ewes $(40 \pm 2.6 \mathrm{~kg})$ fitted with permanent rumen fistulas were used for rumen fermentation trials as the source of inoculum for in vitro rumen fermentation trials.

All animals were housed in individual cages. The sheep were fed with basal diet comprised of A.halimus silage treated with or without enzymes, ad libitum, and barley grain ( $300 \mathrm{~g} /$ day). The diet was formulated to meet maintenance requirements (NRC 1994).

A. halimus was moistened into DM content in an average of $40 \%$ without or with addition of $\mathrm{ZADl}^{\circledR}$ or $\mathrm{ZAD}^{\circledR}(2 \mathrm{~L} /$ $1000 \mathrm{~kg}$ of $A$. halimus, in fresh matter basis) and molasses (5 $\%$ A. halimus, in fresh matter basis), and then sealed with a polyethylene sheet to be ensiled for 4 weeks in each treatment. Every diet was prepared a month before feeding to animals. Barley grain (300 g/head/day) was fed as an energy supplement during the experimental period for all diets. Four experimental diets comprised of: AH silage (leaves and stems; D 1); AH silage treated with ZAD ${ }^{\circledR}$ and barley (D2), AH silage treated with $\mathrm{ZAD} 2^{\circledast}$ and barley (D3) and $\mathrm{AH}$ silage treated with a combination of $\mathrm{ZADl}^{\circledR}$ and $\mathrm{ZAD}^{\circledR}(1: 1)$ and barley (D4). For all treatments, A. halimus was offered to animals ad libitum twice daily at 09.00 and 16.00 hours, while barley grain was given once daily at 10.00 hours.

The two recently developed enzyme cocktails $\mathrm{ZADl}^{\circledR}$ and ZAD2 $^{\circledR}$ (patent No: 22155) were obtained from the laboratory of the Rumen Ecology Center, Animal Production Department, Faculty of Agriculture, Ain Shams University, Cairo, Egypt, according to the procedure of (Gado 1997). Both ZAD $1^{\circledast}$ and ZAD $2^{\circledast}$ are live anaerobic bacteria with their enzymes (Table 1 ).

\section{Metabolism study}

Each metabolism trial was conducted for 3 weeks as a preliminary period and 1 week for sample collection. All animals were kept individually in stainless metabolic cages at room temperature and had free access to water. Beneath each cage was a stainless steel screen having $4 \mathrm{~mm}$ mesh to retain feces but free passage of urine, which was collected through a

Table 1 Composition of exogenous enzymest of ZAD $1^{\circledR}$ and ZAD2 ${ }^{\circledR}$

\begin{tabular}{|c|c|c|c|c|}
\hline am & † & a-amylase§ & TI & \\
\hline$D$ & & & & \\
\hline & & & & \\
\hline \multicolumn{5}{|c|}{ 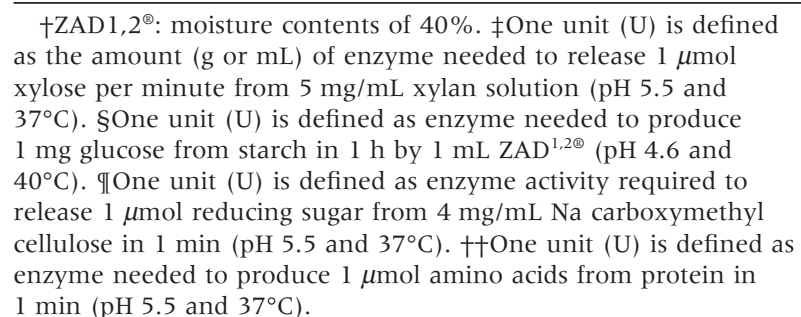 } \\
\hline
\end{tabular}


funnel. Feces and urine were collected once daily before the morning feeding and stored at $-10^{\circ} \mathrm{C}$ for later analysis.

The samples of feces were mixed within 7 day's collections, composited and stored for later routine analyses. Fecal samples were dried at $60^{\circ} \mathrm{C}$ for $72 \mathrm{~h}$ and then ground through a $1 \mathrm{~mm}$ screen using a Wiley mill grinder (Arthur $\mathrm{H}$. Thomas, Philadelphia, PA, USA).

Conventional analysis of feed and fecal samples was carried out according to AOAC (1997) for DM, crude ash, N, crude fiber (CF) and ether extract (EE). The neutral detergent fiber (NDF) and acid detergent fiber (ADF) were analyzed by the method of Van Soest et al. (1991) using ANKOM200 Fibre Analyzer unit (ANKOM Technology Corporation, Macedon, NY, USA). The NDF was assayed without use of an alpha amylase but with sodium sulfite. Both NDF and ADF are expressed without residual ash. Urinary $\mathrm{N}$ was analyzed according to AOAC (1997).

The value of total digestible nutrients (TDN) intake was calculated according to NRC (2001) using values of digestible nitrogen free extract (NFE), CP, EE and CF.

\section{Ruminal fermentation activities}

In vitro zero order technique (Carroll \& Hungate 1954) was applied for measuring rates of ammonia $\left(\mathrm{NH}_{3}-\mathrm{N}\right)$ and volatile fatty acids production. Rumen contents were collected from three rumen fistulated Barki ewes fed on each experimental diet consecutively at 08.00 hours before feeding and at 1,3 and $6 \mathrm{~h}$ after feeding.

The rumen samples were mixed, homogenized and filtered through a sieve with a pore size of $1 \mathrm{~mm}$ under continuous $\mathrm{CO}_{2}$ flushing, closed with a tightly fitting rubber with an outlet Bunsen valve and incubated at $39^{\circ} \mathrm{C}$ in a thermostatically controlled water bath. Each sample was composed of two-thirds fibrous material and one-third liquid (El-Shazly $\delta$ Hungate 1965). At zero time incubation, two sub-samples were transported, poured into another jar containing formalin ( $1 \mathrm{~mL} / 100 \mathrm{~g}$ rumen contents) and swirled vigorously to stop metabolic activity.

After $1 \mathrm{~h}$ incubation, rumen samples treated with formalin were used to estimate $\mathrm{NH}_{3}-\mathrm{N}$ and total volatile fatty acids (tVFA) concentration. Rumen samples taken at zero and at $1 \mathrm{~h}$ fermentation were strained through four layers of cheesecloth. Fifty milliliters of rumen liquor were deproteinized using $0.03 \mathrm{~mol} / \mathrm{mL}$ of sulphuric acid $(50 \mathrm{~mL})$ and the volume was diluted with water to $500 \mathrm{~mL}$ in a volumetric flask and filtered. The supernatant was used for determination of $\mathrm{NH}_{3}-\mathrm{N}$ concentration using $(\mathrm{MgO})$ distillation method (Al-Rabbat et al. 1971) and tVFA were estimated using steam distillation as described by Warner (1964).

The microbial protein (MP) synthesized in the rumen fed the four experimental diets were calculated by the following equation (Borhami et al. 1992):

$$
\begin{aligned}
\mathrm{MP}(\mathrm{g} / \text { day })= & \text { tVFA production }(\mathrm{mol} / \text { day }) \\
& \times 2 \times 13.48 \times 10.5 \times 6.25 / 100
\end{aligned}
$$

tVFA production $=$ tVFA concentration $\quad(\mathrm{mol} / 100 \mathrm{~mL}$; obtained from the in vitro zero order technique) $\times 10 \times$ total rumen digesta $(\mathrm{L})$.

Multiplication by 10 obtains the rate of VFA production/ $\mathrm{h} / \mathrm{L}$, while multiplication by 24 obtains the rate of VFA production/24 h (i.e. day)/L.

It was assumed that 1 mol tVFA yields 2 moles ATP (Walker 1965), 1 mole ATP produces $13.48 \mathrm{~g}$ microbial cells (DM basis) (Borhami et al. 1979) and N concentration of microbial cells is $10.5 \%$ (Hungate 1965). Rumen digesta weight $(\mathrm{kg})$ was estimated using the colorimetric method of chromium ethylenediaminetetraacetate (Cr-EDTA) according to the method of El-Shazly et al. (1976).

\section{Statistical analysis}

Data were statistically analyzed according to a randomized block design using the PROC MIXED procedure of SAS (2002) according to the following statistical model:

$$
\mathrm{Y}_{\mathrm{ijk}}=\mu+\mathrm{D}_{\mathrm{i}}+\mathrm{T}_{\mathrm{j}}+(\mathrm{D} * \mathrm{~T})_{\mathrm{ij}}+\mathrm{e}_{\mathrm{ijk}}
$$

where:

$\mathrm{Y}_{\mathrm{ijk}}=$ observation on individual $\mathrm{k}, \mu=$ overall mean, $D_{i}=$ fixed effect of the $i^{\text {th }}$ diet, $T_{j}=$ fixed effect of the $j^{\text {th }}$ time, $\left(D^{*} T\right)_{i j}=$ interaction between diet and time, $e_{i j k}=$ random error $=\hat{o}^{2}$. Tukey's test was used for the multiple comparisons among mean values for different treatments.

\section{RESULTS}

Treating of $A$. halimus with enzymes reduced its contents of CF, NDF and ADF without affecting CP and EE contents. The combination of $\mathrm{ZADl}^{\circledR}+\mathrm{ZAD} 2^{\circledR}$ and ZAD2 ${ }^{\circledR}$ were more effective in lowering $\mathrm{CF}, \mathrm{NDF}$ and ADF than $\mathrm{ZADl}^{\circledR}{ }^{\circledR}$ (Table 2).

Addition of $A$. halimus silage treated with enzymes (D2, D3 and D4) improved the intake as air dried or TDN (g/day) compared to Dl (A.halimus silage). However, when compared based on DM, Dl had the highest intake, although enzyme-treated groups (D2, D3 and D4) decreased $(P<0.001)$ it (Table 3). D2 and D3 had almost the same total DM intake; however, D2, D3 and D4 almost had the same TDN/ total DM intake compared to Dl which had the lowest $(P<0.001)$ percent. All treated diets improved $(P=0.032)$ the intake of air dried $A$. halimus silage. All

Table 2 Chemical composition of ingredients used in the experimental diets ( $\mathrm{g} / \mathrm{kg}$ dry matter)

\begin{tabular}{lrllll}
\hline & Barley & $\begin{array}{l}\text { Atriplex halimus } \\
\text { silage }\end{array}$ & $\begin{array}{l}\text { A. halimus silage } \\
\text { treated with ZAD }{ }^{\circledR}\end{array}$ & $\begin{array}{l}\text { A. halimus silage } \\
\text { treated with ZAD2 }{ }^{\circledR}\end{array}$ & $\begin{array}{l}\text { A. halimus silage treated } \\
\text { With ZAD }^{\oplus}+\text { ZAD2 }^{\circledR}\end{array}$ \\
\hline Organic matter & 960.0 & 766.0 & 760.0 & 761.0 & 759.0 \\
Crude protein & 118.9 & 117.4 & 115.2 & 114.4 & 113.7 \\
Crude fiber & 86.3 & 248.2 & 226.5 & 222.5 & 224.9 \\
Neutral detergent fiber & 189.0 & 551.8 & 403.0 & 406.0 & 401.2 \\
Acid detergent fiber & 72.0 & 339.6 & 253.0 & 258.0 & 250.2 \\
Ether extract & 29.3 & 19.2 & 19.3 & 404.4 & 18.8 \\
Nitrogen free extract & 725.3 & 380.7 & 399.2 & 401.8 \\
\hline
\end{tabular}


Table 3 Feed intake, nutrient digestibility and nitrogen utilization of sheep fed $\dagger$ Atriplex halimus silage treated with enzymes and barley

\begin{tabular}{|c|c|c|c|c|c|c|}
\hline \multirow[t]{2}{*}{ Items } & \multirow{2}{*}{$\begin{array}{l}\text { A. halimus } \\
\text { silage and } \\
300 \text { g barley } \\
\text { (D1) }\end{array}$} & \multirow{2}{*}{$\begin{array}{l}\mathrm{ZADl}^{\circledR} \text { and } \\
300 \mathrm{~g} \text { barley } \\
\text { (D2) }\end{array}$} & \multicolumn{2}{|c|}{ A. halimus silage treated with enzymes of } & \multirow[t]{2}{*}{ SEM } & \multirow[t]{2}{*}{$P$-value } \\
\hline & & & $\begin{array}{l}\mathrm{ZAD}^{\circledR} \text { and } 300 \mathrm{~g} \\
\text { barley (D3) }\end{array}$ & $\begin{array}{l}\mathrm{ZAD}^{\circledR}+\mathrm{ZAD} 2^{\circledR} \text { and } \\
300 \mathrm{~g} \text { barley }(\mathrm{D} 4)\end{array}$ & & \\
\hline \multicolumn{7}{|l|}{ A. halimus intake, g/day } \\
\hline Air dried & $571.8^{\mathrm{c}}$ & $1106.6^{\mathrm{a}}$ & $1091.5^{\mathrm{ab}}$ & $978.3^{\mathrm{b}}$ & 19.16 & 0.032 \\
\hline Dry matter (DM) & $510.7^{\mathrm{a}}$ & $390.8^{\mathrm{b}}$ & $390.1^{\mathrm{b}}$ & $346.1^{\mathrm{c}}$ & 16.72 & $<.0001$ \\
\hline Total DM intake & $776.7^{\mathrm{a}}$ & $656.8^{\mathrm{b}}$ & $656.1^{\mathrm{b}}$ & $612.1^{\mathrm{b}}$ & 17.73 & $<.0001$ \\
\hline Total TDN intake, g/day & $407.0^{\mathrm{a}}$ & $374.8^{\mathrm{b}}$ & $383.2^{\mathrm{ab}}$ & $350.6^{\mathrm{b}}$ & 15.45 & $<.0001$ \\
\hline TDN/Total DM intake, \% & $52.4^{\mathrm{b}}$ & $57.1^{\mathrm{a}}$ & $58.4^{\mathrm{a}}$ & $57.3^{\mathrm{a}}$ & 2.23 & $<.0001$ \\
\hline \multicolumn{7}{|l|}{ Digestibility, $\%$} \\
\hline Dry matter & $57.9^{\mathrm{b}}$ & $62.1^{\mathrm{a}}$ & $63.8^{\mathrm{a}}$ & $61.8^{\mathrm{a}}$ & 2.88 & $<.0001$ \\
\hline Organic matter & $60.8^{\mathrm{b}}$ & $65.2^{\mathrm{a}}$ & $66.8^{\mathrm{a}}$ & $65.2^{\mathrm{a}}$ & 2.60 & $<.0001$ \\
\hline Crude protein & $43.5^{\mathrm{c}}$ & $53.2^{\mathrm{b}}$ & $56.6^{\mathrm{a}}$ & $55.7^{\mathrm{ab}}$ & 3.65 & $<.0001$ \\
\hline Crude fiber & $39.8^{c}$ & $49.5^{b}$ & $52.7^{\mathrm{a}}$ & $50.7^{\mathrm{ab}}$ & 2.40 & $<.0001$ \\
\hline Neutral detergent fiber & $55.8^{c}$ & $60.2^{\mathrm{b}}$ & $62.2^{\mathrm{ab}}$ & $65.0^{\mathrm{a}}$ & 2.03 & $<.0001$ \\
\hline Ether extract & $64.6^{\mathrm{c}}$ & $74.8^{\mathrm{ab}}$ & $76.1^{\mathrm{a}}$ & $72.3^{\mathrm{b}}$ & 3.80 & $<.0001$ \\
\hline Nitrogen free extract & 72.8 & 72.5 & 73.0 & 71.3 & 3.70 & 0.0016 \\
\hline \multicolumn{7}{|l|}{ Nitrogen utilization, g/day } \\
\hline Nitrogen intake & $14.7^{\mathrm{a}}$ & $12.26^{\mathrm{b}}$ & $12.2^{\mathrm{b}}$ & $11.35^{c}$ & 1.02 & $<.0001$ \\
\hline Nitrogen retention & $0.81^{\mathrm{c}}$ & $2.08^{\mathrm{b}}$ & $2.65^{\mathrm{a}}$ & $2.34^{\mathrm{ab}}$ & 0.06 & $<.0001$ \\
\hline $\begin{array}{l}\text { Nitrogen retention / Nitrogen } \\
\text { absorption }\end{array}$ & $12.7^{c}$ & $31.96^{\mathrm{b}}$ & $40.2^{\mathrm{a}}$ & $37.04^{\mathrm{a}}$ & 3.12 & $<.0001$ \\
\hline
\end{tabular}

†All diets supplemented with $300 \mathrm{~g}$ air-dried barley per head per day or $266 \mathrm{~g}$ DM/head/day. ${ }^{\mathrm{a}, \mathrm{b}, \mathrm{c}}$ Means in the same row with different superscripts are significantly different $(P<0.05)$.

enzyme-treated diets (D2, D3 and D4) improved $(P<0.001)$ OM, CP, CF, NDF and EE digestibilities compared with D1. No differences $(P=0.0016)$ were observed for NFE digestibility between different diets. The D3 tended to show higher nutrient digestibility than D2 and D4. Feeding $A$. halimus silage treated with different enzymes (D2, D3 and D4) to sheep lowered $(P<0.001)$ nitrogen retention $(\mathrm{NR})$ and nitrogen retention /nitrogen absorption (NA) ratio (NR/NA) compared to untreated A. halimus silage (D1) which increased $(P<0.001)$ nitrogen intake $(\mathrm{NI})$ compared to other diets (Table 3 ).

No differences $(P>0.05)$ were observed for ruminal $\mathrm{pH}$ among the dietary treatments. Sheep fed on ZAD2 ${ }^{\circledR}$ treated A.halimus silage (D3) showed numerically higher values for all measured rumen fermentation parameters. Animals fed on $\mathrm{ZAD} 2^{\circledR}+\mathrm{ZAD} 2^{\circledR}$ treated $A$. halimus silage (D4) had higher rumen fermentation parameters than ZAD $1{ }^{\circledR}$ treated or untreated $A$. halimus silage. The concentration of ruminal tVFA, $\mathrm{NH}_{3}-\mathrm{N}$, and microbial protein production was increased with advancing of time to reach the maximum value around $3 \mathrm{~h}$ after feeding and then later decreased (Table 4).

\section{DISCUSSION}

\section{Composition of enzymes in treated or untreated $A$. halimus silage}

Treating forages like A.halimus with exogenous fibrolytic enzymes is accompanied, in most cases, with degradation of various fiber fractions. In our study, $\mathrm{ZADl}^{\circledR}, \mathrm{ZAD}^{\circledR}{ }^{\circledR}$ and their combination reduced $\mathrm{CF}$ content by $8.7,10.4$ and $9.4 \%$; NDF by $27,26.4$ and $27.3 \%$; ADF by 25.5, 24 and $26.3 \%$, respectively. This may be due to reduction of structural polysaccharide fractions (Facchini et al. 2011). The difference in response between $\mathrm{ZADl}^{\circledR}$ and $\mathrm{ZAD} 2^{\circledR}$ or their combination depends on their different enzyme contents (Table 1). Gado et al. (2009) showed that ensiling rice straw, bagasse and corn stalks with $\mathrm{ZAD}^{\circledR}$ decreased the CF in a range of $30.3 \%$ to $36.6 \%$. The present study showed that enzyme-treated or untreated $A$. halimus silage can be used as a basal diet for ruminant production in arid and semi-arid regions (Haddi et al. 2009; Otal et al. 2010).

\section{Feed intake, nutrient digestibility and $\mathbf{N}$ utilization}

Feeding $A$.halimus silage treated with enzymes (i.e. D2, D3 and D4) to sheep increased its air dried intake. This may be due to increased palatability of the diet due to sugars released by pre-ingestive fiber hydrolysis. However, post-ingestive enzyme effects, such as increased digestion rate or extent of digestion (Krueger et al. 2008) may increase hydrolytic activity in the rumen to reduce gut fill and enhance feed intake (Adesogan 2005). In contrast, comparing feed intake on a DM basis, feeding $A$. halimus silage treated with $\mathrm{ZAD} 1^{\circledR}$ or ZAD ${ }^{\circledR}$ caused a decreased total DM intake. This may be due to the moisture concentration 
Table 4 Ruminal $\mathrm{pH}$, total volatile fatty acids (tVFA), $\mathrm{NH}_{3}-\mathrm{N}$ and microbial protein production at different times of incubation of sheep fedt Atriplex halimus silage treated with enzymes and barley

\begin{tabular}{|c|c|c|c|c|c|c|}
\hline \multirow[t]{2}{*}{ Time after feeding $(\mathrm{h})$} & \multirow{2}{*}{$\begin{array}{l}\text { A. halimus silage } \\
\text { and } 300 \mathrm{~g} \\
\text { barley (D ) }\end{array}$} & \multicolumn{3}{|c|}{ A. halimus silage treated with enzymes of } & \multirow[t]{2}{*}{ SEM } & \multirow[t]{2}{*}{$P$-value } \\
\hline & & $\begin{array}{l}\mathrm{ZAD} 1^{\circledR} \text { and } \\
300 \mathrm{~g} \text { barley } \\
(\mathrm{D} 2)\end{array}$ & $\begin{array}{l}\text { ZAD2 }{ }^{\circledR} \text { and } \\
300 \mathrm{~g} \text { barley } \\
\text { (D3) }\end{array}$ & $\begin{array}{l}\mathrm{ZAD}^{\circledR}+\mathrm{ZAD}^{\circledR} \\
\text { and } 300 \mathrm{~g} \\
\text { barley }(\mathrm{D} 4)\end{array}$ & & \\
\hline \multicolumn{7}{|l|}{$\mathrm{pH}$} \\
\hline 0 & 6.91 & 6.79 & 6.79 & 6.83 & 0.06 & \\
\hline 1 & 6.63 & 6.56 & 6.61 & 6.67 & 0.06 & \\
\hline 3 & 6.32 & 6.28 & 6.28 & 6.31 & 0.05 & \\
\hline 6 & 6.76 & 6.68 & 6.65 & 6.7 & 0.06 & \\
\hline Mean & 6.60 & 6.58 & 6.58 & 6.63 & 0.04 & 0.8138 \\
\hline \multicolumn{7}{|c|}{ tVFA, mmol/l00 mL rumen liquor } \\
\hline 0 & 6.53 & 7.79 & 8.15 & 8.03 & 0.44 & \\
\hline 1 & 7.77 & 8.82 & 9.18 & 8.95 & 0.48 & \\
\hline 3 & 9.65 & 11.56 & 12.41 & 12.1 & 0.44 & \\
\hline 6 & 7.66 & 8.4 & 8.8 & 8.66 & 0.49 & \\
\hline Mean & $7.90^{c}$ & $9.14^{\mathrm{b}}$ & $9.64^{\mathrm{a}}$ & $9.44^{\mathrm{ab}}$ & 0.41 & $<.0001$ \\
\hline \multicolumn{7}{|c|}{$\mathrm{NH}_{3}-\mathrm{N}, \mathrm{mg} \mathrm{N} / 100 \mathrm{~mL}$ rumen liquor } \\
\hline 0 & 8.96 & 12.08 & 12.51 & 12.16 & 0.36 & \\
\hline 1 & 10.02 & 13.44 & 14.64 & 13.66 & 0.39 & \\
\hline 3 & 11.93 & 15.36 & 16.86 & 15.69 & 0.38 & \\
\hline 6 & 9.66 & 13.18 & 14.18 & 13.34 & 0.39 & \\
\hline Mean & $10.14^{\mathrm{c}}$ & $13.52^{\mathrm{b}}$ & $14.55^{\mathrm{a}}$ & $13.71^{\mathrm{ab}}$ & 0.31 & 0.0071 \\
\hline \multicolumn{7}{|c|}{ Microbial protein production (g/day) } \\
\hline 0 & 15.52 & 19.86 & 28.09 & 20.92 & 3.48 & \\
\hline 1 & 19.65 & 24.67 & 38.88 & 28.31 & 3.41 & \\
\hline 3 & 32.44 & 41.64 & 57.97 & 43.79 & 3.62 & \\
\hline 6 & 15.64 & 21.92 & 31.25 & 23.58 & 3.61 & \\
\hline Mean & $20.81^{c}$ & $27.02^{\mathrm{b}}$ & $39.05^{a}$ & $29.15^{\mathrm{b}}$ & 3.42 & 0.0003 \\
\hline
\end{tabular}

†All diets supplemented with $300 \mathrm{~g}$ air-dried barley per head per day or $266 \mathrm{~g}$ DM/head/day. ${ }^{\mathrm{a}, \mathrm{b}, \mathrm{c}}$ Means in the same row with different superscripts are significantly different $(P<0.05)$.

of silage (up to $60 \%$ moisture) which may increase the satiety of sheep, resulting a decreased feed intake (Forbes 2007). However, Khattab et al. (2011) found that diets treated with the same enzyme preparations did not affect feed intake. Intake of TDN of sheep fed enzyme-treated $A$. halimus silage (i.e. D2, D3 and D4) was lower than for those fed A. halimus silage untreated with enzymes (i.e. Dl). However, when the TDN intake was compared as a percent from total DM intake, the results may be completely reversed. At the same time, comparing obtained TDN intake (\%) for enzyme-untreated or treated $A$. halimus silage showed that these values were higher than the tabular value from NRC (1994) for daily maintenance requirements from TDN intake (\%) which is about $54.5 \%$ TDN at $45 \mathrm{~kg}$ of body weight. This may give an indication for sufficient energy allowances for the animals in different treatments.

A. halimus silage treated with ZAD2 ${ }^{\circledR}$ showed numerically highest values for nutrient digestibility with the exception of NDF and NFE. The relatively higher digestibilities with ZAD $2^{\circledR}$ than $\mathrm{ZAD} 1^{\circledR}+\mathrm{ZAD}^{\circledR}$ may be related to its enzyme contents. ZAD $2^{\circledR}$ contains higher xylanase, cellulase and a-amylase than ZAD ${ }^{\circledR}$ which encourages pre-ingestive fiber hydrolysis. Addition of both enzymes together was less effective than
$\mathrm{ZAD}^{\circledR}{ }^{\circledR}$. This is related with higher enzyme concentrations when both enzymes were added; resulting in preventing binding of enzymes to substrate receptors, which reduced proportional attachment by ruminal microorganisms to fiber (Treacher \& Hunt 1996). These results are similar to other reports that had shown an increase in nutrient digestibility with the same exogenous fibrolytic enzymes of $\mathrm{ZADl}^{\circledR}$ and ZAD2 $^{\circledR}$ (Khattab et al. 2011 ; Kholif et al. 2012). Exogenous fibrolytic enzymes would increase fiber digestion by many mechanisms, increasing the rate of ruminal digestion of the potentially digestible fiber (Yang et al. 1999), reducing digesta viscosity (Hristov et al. 2000) and alterations in ruminal fermentation (Nsereko et al. 2002). It also enhances attachment and colonization to the plant cell wall by ruminal microorganisms (Wang et al. 2001; Chung et al. 2012) or by synergism between exogenous enzymes and enzymes in rumen fluid (Eun et al. 2006). They demonstrated a synergism between exogenous enzymes and ruminal enzymes such that the net combined hydrolytic effect in the rumen was much greater than that estimated from individual enzyme activities. Moreover, Wang et al. (2001) reported that supplementation diets with enzymes increased numbers of non-fibrolytic and fibrolytic bacteria in a batch culture system with 
rumen fluid. Stimulation of rumen microbial numbers by the use of enzymes could result in higher microbial biomass, which would provide more polysaccharidase activity to digest different feeds and degrade secondary metabolites. Although this possibility may not be supported by Nsereko et al. (2002) or Krueger et al. (2008), who showed that while cellobiose and glucose utilizing bacteria were stimulated, effects on the fibrolytic population were negligible. Our results indicate that enzyme supplementation could increase the quantity of microbial protein available to animal metabolism, and this may increase fiber digestibility and the metabolizable energy density of diets.

Although addition of enzyme-treated A.halimus silage had decreased $(P<0.001) \mathrm{N}$ intake per DM consumption, with improving $(P<0.001)$ CP digestibility especially with ZAD $2^{\oplus}$ and $\mathrm{ZAD}^{\oplus}+{ }^{\oplus}$ ZAD2 ${ }^{\oplus}$, nitrogen retention was higher than the other diets. This is an indication of improvements in utilization of $\mathrm{N}$ in tree fodder forages as a result of application of the exogenous fibrolytic enzymes being contained in $\mathrm{ZAD}^{\circledR}$.

\section{Ruminal fermentation and microbial protein synthesis}

Addition of $\mathrm{ZAD}^{\circledR}$ and $\mathrm{ZADl}^{\oplus}+\mathrm{ZAD}^{\circledR}{ }^{\circledR}$ treated $A$. halimus silage improved $(P<0.001)$ the production of tVFA and $\mathrm{NH}_{3}-\mathrm{N}$. The increase in ruminal tVFA and $\mathrm{NH}_{3}-\mathrm{N}$ suggested that $\mathrm{ZAD}^{\circledR}$ and $\mathrm{ZADl}^{\oplus}+\mathrm{ZAD}^{\oplus}$ treated $A$. halimus silage was more efficient and yielded more tVFA and $\mathrm{NH}_{3}-\mathrm{N}$ than control. Results of tVFA suggested that feeding of $\mathrm{ZAD}^{\circledR}$ treated A. halimus silage improved anaerobic ruminal fermentation which stimulated it to yield more VFA. This improved yield of VFA may be due to the increases of OM digestibility in treated diets, especially D3. Increased $\mathrm{NH}_{3}-\mathrm{N}$ concentration in animals fed $\mathrm{ZAD}^{\circledR}$ and $\mathrm{ZADl}^{\oplus}+$ $\mathrm{ZAD}^{\circledR}{ }^{\circledR}$ (i.e. $\mathrm{D} 3$ and $\mathrm{D} 4$ ) diets supports its capability to enhance rumen protein degradation, probably because of its protease enzyme contents (Gado et al. 2009; Khattab et al. 2011). It may be also due to the fact that exogenous enzymes had a synergism with endogenous enzymes, especially the proteolytic enzyme, or enhanced the activity of microorganisms.

Rumen microbial protein of sheep was improved by feeding A.halimus silage treated with $\mathrm{ZAD}^{\circledR}$ or $\mathrm{ZADl}^{\oplus}+\mathrm{ZAD}^{\circledR}$. It is well known that microbial protein synthesis is a good indicator of beneficial effect of feed utilization. Microbial protein has the most significant impact on both quantity and quality of metabolizable protein absorbed from the small intestine. These results suggest that $A$. halimus silage treated with $\mathrm{ZAD} 2^{\circledast}$ or $\mathrm{ZAD} 1^{\oplus}+\mathrm{ZAD} 2^{\circledR}$ may be more efficient for enhancing fiber digestibility, resulting in provision of more nutrients for ruminal microorganisms which are beneficial for the growth of microbes.

\section{Conclusions}

Feeding A.halimus silage treated with $\mathrm{ZADl}^{\circledR}$ and $\mathrm{ZAD}^{\circledR}{ }^{\circledR}$, separately or in combination, to sheep improved digestibility coefficients, nitrogen retention and utilization and rumen fermentation (tVFA and $\mathrm{NH}_{3}-\mathrm{N}$ ), as well as microbial protein production. The enzyme cocktail of ZAD2 ${ }^{\circledR}$ was more effective than ZAD $1^{\circledR}$ followed by ZAD $1^{\circledast}+\mathrm{ZAD}^{\circledR}{ }^{\circledR}$ combination.

However, there is a need for further studies on the effect of these exogenous enzymes on ruminal microbial populations, animal performance properties and the mechanisms of actions between ZAD $1^{\oplus}$ and ZAD $2^{\oplus}$ with endogenous enzymes and microbes.

\section{ACKNOWLEDGMENT}

The authors acknowledge the IAEA, Vienna, Austria, Research Contract number MEX16307 within the D3.10.27 Coordinated Research Project. [Correction added on 9 October 2014, after first online publication: Acknowledgement section has been added.]

\section{REFERENCES}

Abd El-Rahman HH, Mohamed MI, Gehad AEA, Awadallah IM. 2006. Ameliorating the anti-nutritional factors effect in Atriplex halimus on sheep and goats by ensiling or polyethylene glycol supplementation. International Journal of Agriculture and Biology 8, 766-769.

Adesogan AT. 2005. Improving forage quality and animal performance with fibrolytic enzymes. Florida Ruminants Nutrition Symposium, pp. 91-109. Gainesville, FL.

Aharonson Z, Shani J, Sulman F. 1969. Hypoglycaemic effect of the salt bush (Atriplex halimus) - a feeding source of the Sand Rat (Psammomys obesus). Diabetologia 5, 379-383.

Al-Owaimer AN, El-Waziry AM, Koohmaraie M, Zahran SM. 2011. The use of ground date pits and Atriplex halimus as alternative feeds for sheep. Australian Journal of Basic and Applied Sciences 5, 1154-1161.

Al-Rabbat MF, Baldwin RL, Weir WC. 1971. In vitro ${ }^{15}$ Nitrogen-tracer technique for some kinetic measures of ruminal ammonia. Journal of Dairy Science 54, 1150-1161.

AOAC. 1997. Association of Official Analytical Chemists. Official Methods of Analysis, 16th edn. AOAC, Arlington, VA, USA.

Borhami BE, El-Shazly K, Abou-Akkada AR, Naga MA, Abaza AM. 1979. Nitrogen $\left(\mathrm{N}^{15}\right)$ utilization and microbial protein synthesis in the rumen of cattle. Journal of Animal Science 49, 1306-1311.

Borhami BE, Fahmy WG, El-Shazly K. 1992. Rumen environment microbial protein synthesis and nitrogen balance in sheep. In: A Proceeding of 'Manipulation of rumen microorganisms'. Inter. Conf. Alexandria, Egypt.

Carroll EJ, Hungate RE. 1954. The magnitude of microbial fermentation in the bovine rumen. Journal of Applied Microbiology 2, 205-214.

Chung YH, Zhou M, Holtshausen L, Alexander TW, McAllister TA, Guan LL, et al. 2012. A fibrolytic enzyme additive for lactating Holstein cow diets: ruminal fermentation, rumen microbial populations, and enteric methane emissions. Journal of Dairy Science 95, 1419-1427.

Elghandour MMY, Salem AZM, Ronquillo M, Bórquez JL, Gado HM, Odongo NE, Peñuelas CG. 2013. Effect of 
exogenous enzymes on in vitro gas production kinetics and ruminal fermentation of four fibrous feeds. Animal Feed Science and Technology 179, 46-53.

El-Shazly K, Ahmed EIA, Naga MA, Borhami BEA. 1976. A colorimetric technique using chromium-ethylene diamine tetra acetate for measuring rumen volume. The Journal of Agricultural Science 87, 369-373.

El-Shazly K, Hungate RE. 1965. Fermentation capacity as a measure of net growth of rumen microorganisms. Applied Microbiology 13, 62-69.

Eun JS, Beauchemin KA, Hong SH, Bauer MW. 2006. Exogenous enzymes added to untreated or ammoniated rice straw: effects on in vitro fermentation characteristics and degradability. Animal Feed Science and Technology 131, 87-102.

Facchini FD, Vici AC, Benassi VM, Freitas LA, Reis RA, Jorge JA, et al. 2011 . Optimization of fibrolytic enzyme production by Aspergillus japonicus C03 with potential application in ruminant feed and their effects on tropical forages hydrolysis. Bioprocess and Biosystems Engineering 34, 10271038.

Forbes JM. 2007. Voluntary Food Intake and Diet Selection of Farm Animals. CABI Publishers, Wallingford, UK.

Gado HM, Salem AZM, Odongo NE, Borhami BE. 2011. Influence of exogenous enzymes ensiled with orange pulp on digestion and growth performance in lambs. Animal Feed Science and Technology 165, 131-136.

Gado HM, Salem AZM, Robinson PH, Hassan M. 2009. Influence of exogenous enzymes on nutrient digestibility, extent of ruminal fermentation as well as milk production and composition in dairy cows. Animal Feed Science and Technology 154, 36-46.

Gado MH. 1997. Effect of enzymatic treatments for poor quality roughage on fibre digestibility and nitrogen metabolism in baladi goats. Egyptian Journal of Nitrition and Feeds 1, 49-56.

Giraldo LA, Tejido ML, Ranilla MJ, Carro MD. 2008. Effects of exogenous fibrolytic enzymes on in vitro ruminal fermentation of substrates with different forage:concentrate ratios. Animal Feed Science and Technology 141, 306-325.

Haddi ML, Arab H, Yacoub F, Hornick JL, Rollin F, Mehennaoui S. 2009. Seasonal changes in chemical composition and in vitro gas production of six plants from Eastern Algerian arid regions. Livestock Research for Rural Development, 21, Article \#47. [cited 21 May 2014]. Available from URL: http://www.lrrd.org/lrrd21/4/hadd21047 .htm

Holtshausen L, Chung YH, Gerardo-Cuervo H, Oba M, Beauchemin KA. 2011. Improved milk production efficiency in early lactation dairy cattle with dietary addition of a developmental fibrolytic enzyme additive. Journal of Dairy Science 94, 899-907.

Hristov AN, McAllister TA, Cheng KJ. 2000. Intraruminal supplementation with increasing levels of exogenous polysaccharide-degrading enzymes: effects on nutrient digestion in cattle fed a barley grain diet. Journal of Animal Science 78, 477-487.

Hungate RE. 1965. The Rumen and Its Microbes. Academic Press, New York.

Khattab HM, Gado HM, Kholif AE, Mansour AM, Kholif AM. 2011. The potential of feeding goats sun dried rumen contents with or without bacterial inoculums as replacement for berseem clover and the effects on milk production and animal health. International Journal of Dairy Science 6, 267-277.
Kholif SM, Gado HM, Morsy TA, El-Bordeny N, Abedo AA. 2012. Influence of exogenous enzymes on nutrient digestibility, blood composition, milk production and its composition as well as milk fatty acids profile in dairy buffaloes. Egyptian Journal of Nitrition and Feeds 15, $13-22$.

Krueger NA, Adesogan AT, Staples CR, Krueger WK, Kim SC, Littell RC, Sollenberger LE. 2008. Effect of method of applying fibrolytic enzymes or ammonia to Bermuda grass hay on feed intake, digestion, and growth of beef steers. Journal of Animal Science 86, 882-889.

Le Houerou HN. 1992. The role of saltbushes (Atriplex spp) in arid land rehabilitation in the Mediterranean Basin: a review. Agroforestry Systems 18, 107-148.

Makkar HPS. 2003. Effects and fate of tannins in ruminant animals, adaptation to tannins and strategies to overcome detrimental effects of tannin rich feeds. Small Ruminant Research 49, 241-256.

Mayberry DE, Masters DG, Vercoe P. 2008. What is the optimal level of barley to feed sheep grazing saltbush? In: 2nd International Salinity Forum. Salinity, Water and Society-global Issues, Local Action, Adelaide, South Australia, CD rom.

Miller DR, Elliott R, Norton BW. 2008a. Effects of an exogenous enzyme, Roxazyme ${ }^{\circledR} \mathrm{G} 2$, on intake, digestion and utilisation of sorghum and barley grain-based diets by beef steers. Animal Feed Science and Technology 145, 159181.

Miller DR, Granzin BC, Elliott R, Norton BW. 2008b. Effects of an exogenous enzyme, Roxazyme ${ }^{\circledR} \mathrm{G} 2$ Liquid, on milk production in pasture fed dairy cows. Animal Feed Science and Technology 145, 194-208.

Norman HC, Dynes RA, Rintoul AJ, Wilmot MG, Masters DG. 2004. Sheep production from saline land - productivity from old man and river saltbush and the value of grain and straw supplements. Procedure of Australian Society of Animal Production 25, 289-289.

Norman HC, Masters DG, Wilmot MG, Rintoul AJ. 2008. Effect of supplementation with grain, hay or straw on the performance of weaner Merino sheep grazing old man (Atriplex nummularia) or river (Atriplex amnicola) saltbush. Grass and Forage Science 63, 179-192.

NRC. 1994. Nutrient Requirements of Sheep, 6th Revised edn. National Academy Press, Washington, DC, USA.

NRC. 2001. Nutrient Requirements of Dairy Cattle, 7th Revised edn. National Academy Press, Washington, DC, USA.

Nsereko VL, Beauchemin KA, Morgavi DP, Rode LM, Furtado AF. 2002. Effect of a fibrolytic enzyme preparation from Trichoderma longibrachiatum on the rumen microbial population of dairy cows. Canadian Journal of Microbiology 48, 14-20.

Otal J, Orengo J, Quiles A, Hevia ML, Fuentes F. 2010. Characterization of edible biomass of Atriplex halimus L. and its effect on feed and water intakes, and on blood mineral profile in non-pregnant Manchega-breed sheep. Small Ruminant Research 91, 208-214.

Pearce KL, Norman HC, Hopkins DL. 2010. The role of saltbush-based pasture systems for the production of high quality sheep and goat meat. Small Ruminant Research 91, 29-38.

Salem AZM, Gado HM, Colombatto D, Eghandour MMY. 2013. Effect of exogenous enzymes on nutrient digestibility, ruminal fermentation and growth performance in beef steers. Livestock Science 154, 69-73. 
Salem AZM, Hassan AA, Khalil MS, Gado HM, Alsersy H, Simbaya J. 2012. Effects of sun-drying and exogenous enzymes on nutrients intake, digestibility and nitrogen utilization in sheep fed Atriplex halimus foliages. Animal Feed Science and Technology 171, 128-135.

Salem AZM, Salem MZM, El-Adawy MM, Robinson PH. 2006. Nutritive evaluations of some browse tree foliages during the dry season: secondary compounds, feed intake and in vivo digestibility in sheep and goats. Livestock Science 127, 251-267.

SAS. 2002. SAS User's Guide: Statistics. Ver 9.0. p. 956. SAS Institute, Cary, NC, USA.

Treacher RJ, Hunt CW. 1996. Recent developments in feed enzymes for ruminant rations. pp. 37-54. In: Proceeding Pacific Northwest Animal Nutrition Conference, Seattle, WA, USA.

Van Soest PJ, Robertson JB, Lewis BA. 1991. Methods for dietary fibre, neutral detergent fibre, and non-starch carbohydrates in relation to animal nutrition. Journal of Dairy Science 74, 3583-3597.

Walker DJ. 1965. Energy metabolism and rumen microorganisms. In: Physiology of Digestion in the Ruminants. Butterowrth Inc., Washington, DC.

Wang Y, McAllister TA, Rode LM, Beauchemin KA, Morgavi DP, Nsereko VL, et al. 2001. Effects of an exogenous enzyme preparation on microbial protein synthesis, enzyme activity and attachment to feed in the rumen simulation technique (Rusitec). British Journal of Nutrition 85, 325-332.

Warner AC. 1964. Production of volatile fatty acids in the rumen: methods of measurement. Nutrition Abstracts and Reviews 34, 339-352.

Yang WZ, Beauchemin KA, Rode LM. 1999. Effects of an enzyme feed additive on extent of digestion and milk production of lactating dairy cows. Journal of Dairy Science 82, 391-403. 